Article

\title{
Institutional Change, Sustainability and the Sea
}

Achim Schlüter ${ }^{1,2}$,, Sarah Wise ${ }^{3,4}$, Kathleen Schwerdtner Mánez ${ }^{1,5}$, Gabriela Weber de Morais ${ }^{1,4}$ and Marion Glaser ${ }^{1}$

1 Leibniz Center for Marine Tropical Ecology (ZMT), Bremen 28359, Germany;

E-Mails: kathleen.schwerdtner@zmt-bremen.de (K.S.M.); gabriela.morais@zmt-bremen.de (G.W.M.); marion.glaser@zmt-bremen.de (M.G.)

2 School of Humanities and Social Sciences, Jacobs University, Bremen 28759, Germany

3 Sustainability Research Center (ARTEC), Bremen 28359, Germany; E-Mail: swise@ marum.de

4 Bremen International Graduate School for Marine Sciences (GLOMAR), University of Bremen, Bremen 28359, Germany

5 Asia Research Center, Murdoch University, Murdoch WA 6150, Australia

* Author to whom correspondence should be addressed; E-Mail: achim.schlueter@zmt-bremen.de; Tel.: +49-421-23800-104; Fax: +49-421-23800-30.

Received: 30 September 2013; in revised form: 29 November 2013 / Accepted: 5 December 2013 / Published: 12 December 2013

\begin{abstract}
Currently, a substantial institutional change is under way for marine and coastal resources. Sustainability plays a major role therein. At the time of writing, roughly $2.3 \%$ of the marine and coastal territory has been declared a Marine Protected Area (MPA). The Convention of Biological Diversity set a target to protect $10 \%$ of the global marine environment by 2020. This move toward enclosure signifies a substantial shift away from mainly open access to at least de jure marine protected areas. What drives institutional change towards MPAs; and what role does sustainability play in this change in governance? In reflecting on these questions, the paper's aim is to begin a dialogue on how the social-ecological system (SES) analytical framework developed by Elinor Ostrom and her collaborators engages differentially with marine and coastal systems. How institutional change takes place depends on the characteristics of the resources considered and the drivers of change for the particular resource. In order to characterize the marine and coastal realm we use the social-ecological system (SES) framework of Elinor Ostrom. Douglas North's theory of institutional change is used to classify the change observed. The marine realm has ambiguous system boundaries and often high resource mobility. Uncertainties about system properties and change are much higher than for terrestrial
\end{abstract}


systems. Interdependencies among different ecosystems are high, necessitating multi-level governance. Institutional change in this sector occurs under strong institutional path dependencies and competing ideologies. All these features make it particularly relevant to think about institutional change, sustainability and the current process of MPA expansion.

Keywords: institutional change; sustainability; marine protected areas; SES-diagnostic framework

\section{Introduction}

Marine governance is a relative latecomer as far as institution-building is concerned. This is observable for coastal areas, but definitely holds true for the open sea. Throughout human history the demand for regulatory institutions for the sea has been low compared to terrestrial areas. The reasons are manifold, including the long-perceived abundance of marine resources, and certain physical properties such as the absence of visible borders. Currently, one can observe a certain catch-up in institutional development within the marine and coastal realm. The pressures on the coast and on the sea have significantly increased in today's crowded world. Many resources have become scarce; and people are increasingly aware of the ocean's importance as an ecosystem service provider. Important goods and services from the sea range from fish and other marine species, to storm protection, carbon absorption, diving grounds, wind mill farming, transportation, mangrove habitat and biodiversity. Many of those services are becoming increasingly scarce, which leads a societal group to reflect on and demand institutional change.

Institutional change is importantly influenced by the physical, ecological and social contexts in which it takes place. The following paper is written by a group of scientists who dedicate their scientific interest to social processes in relation to the coast and the sea, mainly in the tropical belt. The aim of this paper is to begin a dialogue about the ways institutional change differs for the marine and coastal realm; and what distinguishes it from other processes of institutional change. From this perspective it is a review and conceptual paper. There is a scientific discussion under way (raised elsewhere in this special issue) about specific ecosystem characteristics and the implications for institutional analysis [1]. Within the marine and coastal context, the contributions to such a conceptual analysis are very few [2,3]. The authors seek to contribute to this discussion about features of the marine and coastal realm and the linkages to institutional change and sustainability with a synthesis perspective. Rather than focus on one particular case study, we take a broad look at the relationships among social, ecological and institutional characteristics within the marine realm drawing on many different examples from our analyses around the tropical belt (i.e., Costa Rica, The Bahamas, Brazil, Indonesia, and others). Three further qualifications are necessary. 
First, the marine and coastal realm is broad and diverse. The wide range of goods and services provided by the sea make it difficult to proclaim any general statements about the institutional change in relation to the sea. Institutional problems in the marine environment reach from the global issue of acidification, to the health of small coral reefs (where tourists want to dive and fishers want to fish), to remote Islands in the Pacific, where for example, indigenous populations work to adapt to climate change. We also recognize that coastal governance provides different regulation challenges than the open sea. The physical and social characteristics are very diverse; therefore it can be expected that the institutional solutions will also need to be very diverse. Solutions must be associated with different geographical levels and specific governance regimes. Some solutions may have more in common with certain land based resources than with other sea resources. However, there are shared features such as: boundary ambiguity, interconnectedness of ecosystems, enormous complexity and a high degree of uncertainty regarding many ecosystems. The different spatial and temporal levels at which marine resources occur requires multilevel governance. These features are not unique to marine and coastal resources; but they are of particular importance to these resources.

Second, the term "sustainability" has many different meanings requiring that we make our understanding transparent. Discussing the different definitions of the term sustainability would be a paper or a book on its own [4,5]. For the purpose of this paper, we rely on a narrow understanding of sustainability to examine institutional change in the coastal and marine realm as it relates to environmental improvement and the mitigation of collective action problems linked to resource use. As social scientists we are not attempting to judge ecological sustainability. However, for the sake of this paper, we do not need to qualify any empirical situation as being more or less sustainable.

Third, there are many institutional attempts to reach sustainability in relation to the coastal and marine realm. Institutional systems vary from individual transferable quotas (ITQs), to the Kyoto protocol, to fishing regulations, to rules for sewage water treatment for the sea. Here we focus primarily on institutions related to Marine Protected Areas (MPAs). Given the agreement within the Convention of Biological Diversity to increase MPAs globally (from 2.3\% to $10 \%$ by 2020), and the continuous claim that many of the existing MPAs could be considered paper parks [6], the discussion of this particular governance option is prominent.

The paper develops as follows. First, we use the social-ecological system (SES) diagnostic framework to characterize marine and coastal systems. Second, derived from the first step, we discuss the various drivers of institutional change, and finally we draw conclusions on institutions and sustainability in the marine and coastal realm.

\section{Characterizing Marine and Coastal Resources, the SES Framework}

The SES diagnostic framework is a generic framework for analyzing social-ecological systems particularly with respect to collective action and institutions for sustainable resource use. Institutions 
as rules of the game [7] are the interface, regulating what members of the social systems are permitted and forbidden to do in relation to the ecological systems and in relation to themselves [8]. There are no panaceas for institutional solutions fostering sustainable use of the seas as this depends on the characteristics of the ecological system and its respective resources. Additionally, solutions are contingent on the characteristics of the corresponding social systems, namely their structures and the preferences of the actors involved. In many aspects, marine and coastal social-ecological systems are markedly different to other SES. Carving out these differences will improve our understanding of how institutions and sustainability might interconnect in the coastal and marine realm. Table 1 shows the second tier variables of the SES diagnostic framework. We use various items listed there to explore the substantial characteristics of a marine and coastal SES. For this paper we selected the variables we realized to be most important during our research on different marine and coastal regions within the tropical belt (see [3] for a more comprehensive discussion of the applicability of the SES diagnostic framework to a marine environment).

Table 1. Second-tier variables in framework for analyzing an SES.

\begin{tabular}{|c|c|}
\hline \multicolumn{2}{|c|}{$\begin{array}{l}\text { Social, Economic and Political Setting }(\mathrm{S}) \\
\text { : Economic development, S2: Demographic trends, S3: Political stability, } \\
\text { overnment settlement policies, S5: Market incentives, S6: Media organization }\end{array}$} \\
\hline Resource system (RS) & Governance System (GS) \\
\hline RS1: Sector (e.g., water, forests, pasture, fish) & GS1: Government organizations \\
\hline RS2: Clarity of system boundaries & GS2: Non-government organizations \\
\hline RS3: Size of resource system & GS3: Network structures \\
\hline RS4: Human-constructed facilities & GS4: Property-rights system \\
\hline RS5: Productivity of system & GS5: Operational rules \\
\hline RS6: Equilibrium properties & GS6: Collective-choice rules \\
\hline RS7: Predictability of system dynamics & GS7: Constitutional rules \\
\hline RS8: Storage characteristics & GS8: Monitoring and sanctioning processes \\
\hline \multicolumn{2}{|l|}{ RS9: Location } \\
\hline Resource Units (RU) & Users (U) \\
\hline RU1: Resource unit mobility & U1: Number of users \\
\hline RU2 Growth or replacement rate & U2: Socioeconomic attributes of users \\
\hline RU3: Inter action among resource units & U3: History of use \\
\hline RU4: Economic values & U4: Locations \\
\hline RU5: Size & U5: Leadership/entrepreneurship \\
\hline RU6: Distinctive markings & U6: Norms/Social capital \\
\hline \multirow[t]{3}{*}{ RU7: Spatial and temporal distribution } & U7: Knowledge of SES/mental models \\
\hline & U8: Dependence on resources \\
\hline & U9: Technologies used \\
\hline
\end{tabular}


Table 1. Cont.

\begin{tabular}{ll}
\hline \multicolumn{1}{c}{ Interactions (I) } & \multicolumn{1}{c}{ Outcomes (O) } \\
\hline I1: Harvesting levels of different users & O1: Social performances measures \\
I2: Information sharing among users & O2: Ecological performance measures \\
I3: Deliberation processes & O3: Externalities to other SESs \\
I4: Conflicts among users & \\
I5: Investment activities & \\
I6: Lobbying actibities & \\
\hline
\end{tabular}

Related Ecosystem (ECO)

ECO1: Climate patterns, ECO2:Pollution patterns, ECO3: Flows into and out if focal SES

Source: [9].

\subsection{Social, Economic, and Political Settings (S)}

Looking at economic development (S1), demographic trends (S2) and political stability (S3) of the locations where institutional change takes place in relation to MPAs, it is very difficult to generalize. Comparing, for example, Costa Rica with Angola, vast differences are evident. Costa Rica competes globally for wealthy eco-tourists, has a rather moderate fishing fleet, a low birth rate [10] and political stability for the last hundred years. Meanwhile, Angola has difficulty attracting any marine tourists, has a low GDP, relies heavily on any form of income from the sea, has an extremely high birth rate [10] and would not be graded as a place of political stability. However, what these sites have in common is that economic development is dynamic and fish protein is crucial. Coastal populations continue to increase rapidly putting greater pressure on the resource. Many tropical coastal states could be classified as weak with comparatively low administrative capacity.

Market incentives (S5) and proximity to markets are important features for sustainability. In the past certain MPAs were remote from market incentives; however coastal and marine resource markets are increasingly globalized. Examples of this include: the aquaculture fish of Vietnam, which competes with the local catch in a beach restaurant in Colombia; or the Costa Rican land market, where the fisherman and the farmer compete with the international tourist in a "for saleo" (this is the Costa Rican word for a speculative bubble on the land market and stems from the English word "for sale", a sign posted at many Costa Rican coastal plots).

\subsection{The Resource System (RS)}

According to Ostrom [11] and other scholars, Clarity of system boundaries (RS2) is necessary to create a system of sustainable institutions [12]. If resource users can be sure that they will be able to secure any return on investment for themselves (this investment might be a current abstinence of resource use for future benefit), the likelihood that people will invent sustainable institutions is much higher. This explains why some traditional common property regimes such as the Indonesian sasi laut have solely regulated the exploitation of sedentary marine resources (e.g., sea cucumbers, trochus), 
which occur within comparatively clear boundaries. A similar case is the New England lobster fishery (involving a species with little mobility) which is often used as an example of good communal governance [13]. The situation is completely different for mobile species and the open sea. Looking, for example, at highly migratory species such as tuna, turtles or whales, it becomes clear that system boundaries must be understood as either unstable (that the individual systems in which they occur are interconnected [14]), or that system boundaries should be set on a very high geographical level. The last option creates a number of well-known collective action problems [15]. The ecological characteristics responsible for such unclear boundaries in the marine realm also imply high transaction costs for all matters of management, including conservation. Excludability is always a matter of degree and of the associated transaction costs [16]. Although the oceans are increasingly zoned for different purposes, it is difficult to secure these boundaries as we cannot fence the sea.

Issues of zoning and excludability are of special relevance to MPAs. A number of MPAs have failed, with boundaries that are not adequately defined, understood or respected. The underlying reasons are many, ranging from insufficient funding, ineffective participation processes and reduced legitimacy [17]. MPAs can be undermined by a lack of compliance which is often driven by a shortage of livelihood alternatives or eroded trust in governing bodies. Furthermore, local meanings and values of the area are not always well considered in management, leading to resistance. While excludability is pronounced when looking at marine resources, one can see that the transaction costs for excludability vary as technology changes. For example, in Costa Rica all fishing boats will be equipped with a GPS transmitter in the future as part of a government led program to address drug trafficking. In theory, this could make monitoring of MPA boundaries inexpensive and easy to do even from an office in San Jose. In this case, the increased control of the boundaries comes at zero costs as the GPS system is implemented mainly for drug traffic control reasons and MPA protection is only a side product.

Unclearly defined ecological system boundaries also relate to the size of the resource system (RS3). Within marine systems, humans primarily extract animal resources; many of which are highly mobile species (this might change, e.g., looking to future sea grass use, oil and gas extraction, sea mining and site-specific tourism). The productivity (RS5), from a resource extraction point of view (i.e., return per square meter), is small compared for example with a forest, a vineyard or Tokyo city center. Because there is a cost associated with building institutions; and these transaction costs must somehow be carried by the return of the resource; it can be concluded that the size of the required governance system for the marine environment will be larger than for other resource systems [18]. This is certainly evident when looking at nations within the tropical belt with low budgetary possibilities.

Today, it is difficult to find ecosystems that are not influenced by humans. Even in marine environments humans can be seen as ecosystem engineers [19]. Intentionally, and most of the time unintentionally, we change marine ecosystems considerably. Examples include acidification, aquaculture, mangrove destruction, and huge wind park installation. However, in comparison to land-based resources, 
the architectural role of humans (in terms of producing and providing the ecosystem), is rather small. Forests, landscapes, irrigation channels, or alms are the result of human action, provision and investment [14]. As such these are examples of cultural landscapes. In this respect the sea is different: human beings use marine resources (appropriating) but do not provide them [20]. For example, animal breeding has many thousand years of history while large scale aquaculture is a more recent development.

The likelihood of successfully regulating a SES increases with greater understanding and predictability (predictability of system dynamics (RS7)). If we compare our knowledge and understanding of marine and coastal systems with other ecosystems, it seems clear that the level of knowledge and predictability is much lower for the first. Due to the high mobility of many of the resources, the marine ecosystem is characterized by interdependencies, which in turn lead to a complex system with many uncertainties. This relates to the equilibrium properties (RS6) of the marine ecological system. Often these equilibrium properties are not known.

\subsection{Resource Units (RU)}

As mentioned above, humans have primarily used the mobile resource (RU1) of fish. Additionally, it is difficult to establish distinctive markings (RU6) in the sea. Ostrom emphasizes the importance of distinctive markings when describing successful collective cattle ranging and associated land use [11]. The growth or replacement rate (RU2) of the resources used varies substantially. For example, an herbivore fish stock might regenerate rather quickly. Meanwhile, a coral reef, seagrass bed or mangrove forest might take decades or centuries after they have faced substantial damage. This is coupled with a highly interdependent system with significant interaction among resource units (RU3). Within the context of an interdependent system, where the market is globalized but production takes place in localized ecosystems, the economic value of many marine resources does not reflect scarcity within the particular social-ecological system due to high discrepancies in purchasing power. For example, the price of sea cucumber on the international market is so high that it pays for a Colombian fisher to invest many weeks to find the few left in his ecosystem.

All the characteristics described so far seem to make it more difficult to build sustainable institutions for the sea. However, if we look at the spatial and temporal distribution (RU7) of the resource unit, combined with the human uncontrollability of the sea, we might find higher resilience among specific marine resources in comparison to land based resources [14]. Today, it is relatively easy for us to hunt the last tiger, but it may be more difficult to find the last turtle in the sea (this could change with ultrasound technology). This relates back to equilibrium properties and predictability of the system (RS6 and RS7). The resilience of the system may be higher, but this also means that the fluctuations of the ecosystems are greater, leading to increased difficulty in reaching a sustainable institutional system. As an example, think of fish stocks during "el Niño y la Niña" events in the 
upwelling system of the Eastern Tropical Pacific where a very flexible and responsive institutional system is necessary for reaching sustainable exploitation.

\subsection{Governance System (GS)}

Societies and ecosystems interact on and across various spatial, temporal and a range of other levels [21]. Dimensions at which ecological phenomena appear often do not coincide with the institutional levels at which management decisions are made. This leads to mismatches, also known as "the problem of fit" [22,23]. For example, while a lobster fishery might be regulated most effectively at the level of a small bay, sustainable governance for sea turtles implies coordination among several countries across a region. Management of whale populations would need cross-continental cooperation. Looking at ocean acidification, a global governance mechanism seems the only useful way to offer feasible governance. Given the diversity of marine ecosystems and acknowledging that human requirements are also different between sites, regulation must simultaneously occur at various social levels (e.g., villages, countries or even continents) [24]. This makes it extremely difficult to govern in a centralized way, with per se rules which do not incorporate place-specific knowledge and conditions. Ecosystem diversity and the specific social and ecological contexts require polycentric, de-centralized, emerging governance systems [25]. In most cases, sustainable institutions for the sea must be multi-level and nested governance systems [17,26,27].

Comparatively, formal governance and institutions are slow to emerge or are still lacking for the sea. For instance, spatial planning is well established for land based resources, but is just beginning to develop for the sea. This is particularly true for the open ocean, but is relevant for the coast as well, where MPA implementation lags substantially behind terrestrial areas. Even if there are examples of successful governance, many property rights systems (GS4) are undeveloped leading to de facto open access.

Lack of working governance systems also means that the administrative capacity of and knowledge about governing the sea is limited in comparison to other resources. Currently, many highly valued marine and coastal resources are situated in tropical regions (which often correlate with weaker governance abilities of the state (GS1)), emphasizing the reality that substantial barriers exist toward reaching a sustainable institutional system. In the past, when several state institutions emerged to govern non-sea related ecosystems (only recently have traditional rights been granted to stakeholders), there did not exist many environmental non-governmental organizations (GS2). This is markedly different in the current process of institution building, where NGOs are central stakeholders in the process of emerging institutions.

\subsection{Users $(U)$}

It is difficult to generically characterize users of marine and coastal ecosystems. Somehow, the entire world population could be seen as ecosystem users to a smaller or larger degree. For example, 
when considering the ocean as a carbon sink, the number of users (U1 on Table1) would then be seven billion. We focus here on tropical marine ecosystem users which are at the center of our research interest.

The socioeconomic attributes of users (U2) vary substantially. On one side of the spectrum, there are the economically (extremely) vulnerable artisanal fishers whose livelihoods depend heavily on fishing (U8). In some cases, open access fishing rights have social security functions providing a minimum protein source for the most vulnerable [28]. On the other hand of the spectrum, one might find, for example, rich foreign property owners who hold a significant portion of the land on the Costa Rican Pacific Coast, and who want to use the coast to develop marinas or to snorkel without being disturbed by bomb fishers or the smell from fish landings. In between, one finds tourism operators of different sizes, national and international fishing fleets and inhabitants of coastal zones who need the sea and the coast for multiple uses, e.g., as a means of transportation, sewage disposal, or as a buffer to protect their lives and property. Last but not least, stakeholders such as marine scientists and conservationists rely directly on marine ecosystems for their livelihood.

Apart from the socioeconomic differences, marine ecosystem users contrast in other respects. Norms and social capital (U6) vary, for example, between autochthonous users: displaced people searching for a livelihood, all-inclusive tourists, international hotel chains, and sometimes-more-sometimes-less corrupt governments. It is not uncommon to find all those different stakeholders in one place, attempting to use a bay simultaneously. The diversity in resource users only compounds the limited understanding of the resource system. Under such circumstances, where informational feedback loops of the system are not always conclusive, it is very likely that different mental models (U7) and ideologies explaining how the ecosystem functions persist [29-31]. Furthermore, varying explanations might contradict each other. Those contradictions are already obvious within the scientific community [32], but are also relevant when we consider the various conflicts between conservationists and ecosystem users. These conflicts cannot be fully explained by differences in interest, but also by different understandings of the systems.

The technology used (U9) by ecosystem users is varied. We take as an example different fishing techniques. They can range from cyanide, bomb fishing and compressor diving, to turtle excluder devices, ultrasound fishing fleets, or the recreational fishing rod at the end of a cruising yacht. Looking to other sectors would likely reveal a similar diversity.

Obviously, the differences in economic status, technology, knowledge, and so on, do not always lead to generalized conflicts of interest. However, if we want to understand institutional change in the coastal and marine realm, heterogeneity [33,34] and power asymmetries [35,36] of interest groups must be considered. For example, Jentoft [37] describes the substantial conflict of interests between foreign island owners and Miskitos on the Atlantic Coast of Nicaragua. In this case, indigenous people have tried to use MPAs as a tool to reduce foreign land owner rights, and to secure their traditional rights. Often we find the other constellation, in which the tourism industry or powerful property owners use MPAs to improve the value of their properties by excluding poor fishers.

\subsection{Interactions $(I)$}

Within the diverse groups of ecosystem users, we have considerably different harvesting levels (I1). This creates problems among users as well as in the scope of management. Often small-scale artisanal 
fishers clash with the more technology intensive fishers when their fishing groups overlap. Within the tourism sector, there also exists conflict among big foreign development and small locally based industries.

\subsection{Outcomes $(O)$ and Related Ecosystems (ECO)}

The social performance measures $(\mathrm{O} 1)$ are the same as for other common pool resources; however, the ecological performance measures $(\mathrm{O} 2)$ are of particular difficulty for coastal and marine resources. It is more difficult to observe fish abundance, the state of coral reefs, or a sea grass bed than the health of a forest. Externalities to other SESS (O3 and ECO) are of central importance. The concept of static externalities is not able to capture the level of interdependence among different systems [38]. Those interdependencies are often complex and difficult to observe as they exist on a medium to long term basis. Taking a coral reef system as an example, a higher nitrogen intake due to land use changes may not be noticed for several decades before the negative externalities for the reef are observed. In other scenarios, interdependencies exist on a large geographical level (e.g., the $\mathrm{CO}_{2}$ emitted in localized industrial centers negatively affect reefs globally). In the following section, we reflect on those characteristics of the social-ecological system for analyzing which drivers of institutional change might be especially relevant for the marine realm.

\section{Drivers of Institutional Change for the Marine Realm}

There are many theories of institutional change and it is not in the scope of this paper to deliver any comprehensive review of the different approaches (for this see [39-41]). Starting from a conventional economic perspective, as held by the early new institutional economists (see for example [42]), institutional change was seen as mainly driven by shifting scarcities and preferences. Via a fuzzy competition process in the market [43], the society [44] or the political sphere [45], new institutions emerged. If we consider the history of the emergence of environmental institutions, we realize that there is certainly some explanatory power of this theory. Once, when there was an abundance of land, institutions for land rights did not exist. Similarly, when there was an abundance of beavers or air, there were no institutions existing for the regulation of those resources. As scarcity grew, and preferences changed for those goods, institutions began to develop.

There exists a duality regarding marine resources: on one hand, the intense use pressure for protein, tourism and shipping development. On the other hand, the desire to protect resources is extremely high. This illustrates the current move toward institutional change in the marine sector. Scholars of this approach praise the ability of competitive pressures to lead to better (in the sense of better serving human kind) institutions. Certainly, there is greater competition within institutional development and also within the associated markets (e.g., the fish or tourism market). Bromley [46] makes the point that this competition does not work in relation to institutions of sustainability. Future generations cannot defend their interests in a competitive process. Such a pessimistic interpretation only holds true if we believe that our preferences are mainly determined by self-interest and not also by altruism (e.g., toward future generations). For example, this does not reflect climate change policies as current 
generations will most likely not experience any consequences of those institutional changes. In addition, power asymmetries between different stakeholders underscore the question, exactly who among the current generation benefits from certain institutional changes [47]?

Even if shifting scarcities and preferences are often a cause for institutional change, they cannot determine which institutional solutions are finally selected. For that, institutional economics theory provides four different avenues of explanation: relative transaction costs, path dependencies, ideology and power.

\subsection{Transaction Costs}

High (transaction) costs (which also correspond to minimal extraction, such as with deep sea resources) have been an important reason why property rights in many areas of marine resource use did not emerge earlier. In many cases, owning a tree or a plot of land is relatively straight forward, but fencing part of the ocean is extremely difficult. One might be able to demarcate a particular area in the sea (e.g., a coral reef); nevertheless, this will not prevent some resources from moving in and out of that area. It is this combination of low production per square meter of sea with high transaction costs associated with exclusive property rights which can lead to an open access regime. In the past, the price of a fence in many rangeland areas hindered the establishment of individual rights; however it still remains low in comparison to the required costs to create private rights in most parts of the sea. Varying (transaction) costs due to technological change (e.g., the invention of GPS trackers in MPAs as mentioned above, innovation of ITQs or of mobile phones for coordination purposes among fishers), have also influenced sustainability and institutional change in exploiting marine resources. Specific orders from Hong Kong for live fish are now easily and quickly transferred — via traders and patrons - to Indonesian fishers, who then have lower transaction costs to find out which species are in demand.

\subsection{Path Dependencies}

Institutional path dependencies mean that institutions governing a situation today are a result of the institutions which previously governed the system. If a society has a strong tradition in common property regimes or participation, it is likely that new institutional solutions will be similar to the existing ones. Institutional path dependencies could result out of lower set up costs for an existing regime. They also result from network effects among institutions. Often, an institution requires an entire network of fitting institutions to work [48]. Current institutions can limit imagination as well, defining what is considered to be feasible institutional solutions.

Path dependencies seem to play a role in institutional change particularly in relation to marine sustainability. Historically, it is a customary right that marine resources are open access and free to all $[15,49,50]$. We may accept that we are not allowed to enter a privately owned meadow, but it might 
seem strange to us if a fisher prohibited us from swimming in the sea on our Caribbean cruise. That said, in what context would fishers be allowed to fish in areas frequented by recreational tourists?

Perhaps more important are those path dependencies related to protected area management. As indicated above, we have relatively little experience in governing the sea in comparison to other ecosystems. The institutional framework for MPAs has clearly been taken from the blueprint of land based protected areas [50]. However, as shown above, there are substantial differences in the characteristics of land and sea based social-ecological systems. To neglect those differences might endanger ecological, social and economic sustainability of the governance framework [14]. Those path dependencies might not only result from the fact that laws for land based protection have been copied, but also informal institutions. For example, how a government official or scientist approaches people using the ecosystem, or how he or she involves them in the process of institutional change might lead to social unsustainability (for example through the erosion of trust [51]). There is a fluid link among those informal institutions which determine the process of change and the next determinant, ideology. Informal institutions are often a reflection of ideologies, mental models and an individual's understandings of their system.

\subsection{Ideology}

As described above and pointed out by Denzau and North [29], institutional change in systems characterized by uncertainties, and thus with unclear feedback loops, leads to a strong influence of mental models (how humans explain the observed reality) and ideology. The goals of MPAs and drivers of institutional change are manifold. Objectives include scientific research, environmental services, sustainable resource use, environmental education, tourism, and cultural heritage [52]. In response to the 1992 signing of the Convention on Biological Diversity, biodiversity conservation also emerged as a central goal of MPAs [53]. The increased emphasis on biodiversity included additional financial and institutional support for research on the biological effects of MPA design and implementation. Resource management policy has also shifted from single species protection to a broad-scale ecosystem approach to management.

Within the academic literature about MPAs, one can distinguish several "ideological" streams [50]. Historically, there has been a shift in protected area management from a "fortress approach," (state mandated restricted preservation areas in which no extractive activity is allowed), toward increased stakeholder participation, multiple use zoning, and decentralized management [54]. The "early birds" of marine protection frequently emerged from the natural sciences, emphasizing a preservationist perspective. Protectionist approaches sought to gazette off areas of land and sea for the purpose of limited and specific uses, often excluding traditional users and residents for the benefit of an elite few. The main aim was the protection of certain species and "pristine" environment via restricted or prohibited use. This led to a rather top down view, which underemphasized the point: in today's 
crowded world, the sea is also part of the human environment. Often a complete ban of resource use led to severe conflicts, sometimes for the most vulnerable members of society. The method of enforced exclusion from land and sea also led to community protest and resistance. Resistance to protected area policy takes many forms, but can result in high management costs and low compliance. In the last decade, social wellbeing has been incorporated into resource management policies in an effort to increase compliance.

In contrast to early protected area plans, a more bottom up approach developed, which highlights the need for grassroot participation for sustainable institutional change [55]. Proponents suggest that co-management and the devolution of authority lead to a greater investment in sustainable institutions. Co-management gained in popularity becoming a dominant strategy for conservation projects and specifically for common pool resource management. Co-management emerged after conventional, top-down protected area conservation tactics often failed to achieve conservation goals, while further marginalizing local residents [56]. Rampant non-compliance of conservation regulations coupled with a growing awareness about social injustices led to new and innovative conservation strategies. Far from a one-size-fits-all solution, co-management schemes tend to work better under specific scalar and institutional conditions [57,58]. Generally, participation focuses heavily on the inclusion of interested and affected parties. Just how relevant users are identified and integrated into the planning system remains a challenge and open to much critique.

Studying the literature streams, it becomes clear that, due to the complexity of the issue, we cannot be certain what drives sustainable institutional change in this sector. Scientific perspectives might often conflict with the understandings of actual resource users [59]. Furthermore, they play an important role in feeding the policy debate on conservation targets [60] and highlight the role of power within resource management and sustainability.

\subsection{Power}

Power asymmetries between actors have been described by Knight [36] as a determinant of institutional change. Considering the heterogeneities described in section 2.5 about the various users, we realize that power asymmetries also play an important role in understanding institutional change and sustainability for the sea [24]. Local actors are involved in social networks and hierarchies which determine their positions within a society [61]. As a result, their ability to voice and negotiate their interests diverges considerably [62,63]. Clearly, members of social elites with strong networks, greater access to knowledge and sufficient financial resources are far more able to stand up for their interests and to make decisions. In Indonesian fishing communities, dependent fishers (clients) might not even raise their voice in the presence of their patron. Economically and socially dependent, they live in a situation where they have very little freedom of choice. In many countries, access to knowledge and institutional decision making is influenced by race, gender, class, and language. Social elites can have 
a very strong influence on institutional changes. Adhuri [64] has reported a case from Maluku (Indonesia) where community leaders provided the traditional exclusive fishing rights to a fishing company using destructive methods. In return, they received political support and could further strengthen their own social positioning.

\section{Conclusions}

Despite the vast diversity of coastal and marine resources, they nevertheless share characteristics that can be applied to the whole marine and coastal realm, and that define the institutional change in this area. This includes unclear boundaries, the interconnectedness of different ecosystems, high uncertainty due to limited knowledge and the related need for multilevel governance. Ecological characteristics are significant, clearly illustrating the need for a joint perspective of the natural and social sciences. Due to the complexity of marine and coastal systems, there is no single theory or discipline that is able to describe institutional change in the marine and coastal realm.

From this perspective, the SES framework provides an open approach able to integrate different theories [9]. Additionally, the framework is not deterministic, as this would be an injustice to the complexity and unpredictability of the systems analyzed. Marine and coastal social-ecological systems are so diverse that it would not be possible to adapt the SES diagnostic framework to all systems. Adapting the third or fourth tier would be considerably different depending on the resource analyzed. Take, for example, turtle egg harvesters [3,51] verses whale watching tourism operators [65]. Within the field of natural resource use, the SES diagnostic framework incorporates the accrued research on collective action in such diverse fields as forestry, irrigation, agriculture or marine resources [12]. From this perspective, applying the SES framework nevertheless reduces the chance of missing certain aspects of the collective action process. In various analyses, using the SES diagnostic frameworks' variables showed little relevance after more detailed knowledge of the particular case. However, having these variables in the toolbox when approaching the case ensured nothing was overlooked. By comparing collective action in relation to different ecosystems used [54], we can further enhance our understanding of collective action in general but also in a particular field. To compare different ecosystems or cases we need a common generic framework which then enables a comparative assessment [12,55].

Due to the complexity and uncertainty within the marine realm, institutional change is more heavily influenced by different ideologies within certain sectors. There are some common characteristics to marine and coastal ecosystems; however, no one institutional solution exists that can act as a panacea to fit all coastal marine ecosystems. Moreover, polycentric and multi-level institutional solutions are required for doing justice to those diverse social-ecological systems. 


\section{Acknowledgments}

We thank the ZMT (funded by the German and Bremen government) for providing the funds, which have been necessary for coming over the years to those conclusions and writing this article. We also thank all marine and coastal resource users with whom we interact within our work, and last but not least our colleagues from different collaborating institutes around the tropical belt. The comments of two anonymous reviewers have greatly contributed to improve an earlier version of this article.

\section{Conflicts of Interest}

The authors declare no conflict of interest.

\section{References and Notes}

1. Bots, P.; Schlüter, M.; Sendzimir, J. A framework of analyzing, comparing, and diagnosing social-ecological systems. Availabe online: http://www.ecologyandsociety.org/issues/ view.php?sf=84 (accessed on 30 September 2013).

2. Basurto, X.; Gelcich, S.; Ostrom, E. The social-ecological system framework as a knowledge classificatory system for benthic small-scale fisheries. Global Environ. Change 2013, in press.

3. Schlüter, A.; Madrigal, R. The SES framework in a marine setting: Turtle egg harvesting in costa rica. Ration. Moral Mark. 2012, 3, 148-167.

4. Schanz, H. Forstliche Nachhaltigkeit (in Germany); Series in Schriften aus dem Institut für Forstökonomie der Universität Freiburg, Volume 4; Institut für Forstökonomie: Hamburg, Germany, 1996.

5. Glaser, M.; Christie, P.; Diele, K.; Dsikowitzky, L.; Ferse, S.; Nordhaus, I.; Schlüter, A.; Schwerdtner Mañez, K.; Wild, C. Measuring and understanding sustainability-enhancing processes in tropical coastal and marine social-ecological systems. Curr. Opin. Environ. Sustain. 2012, 4, 300-308.

6. World Bank. Scaling up Marine Management - the Role of Marine Protected Areas; World Bank: Washington, DC, USA, 2006.

7. North, D.C. Institutions, Institutional Change and Economic Performance; Cambridge University Press: Cambridge, UK, 1990.

8. Ostrom, E. Understanding Institutional Diversity; Princeton University Press: Princeton, NJ, USA, 2005.

9. Ostrom, E. A diagnostic approach for going beyond panaceas. Proc. Natl. Acad. Sci. USA 2007, 104, 15181-15187.

10. Mundi Index, Country comparisons. Available online: http://www.indexmundi.com/g/ r.aspx? $\mathrm{v}=25$ (accessed on 7 December 2013).

11. Ostrom, E. Governing the Commons: The Evolution of Institutions for Collective Action; Cambridge University Press: Cambridge, UK, 1990.

12. Agrawal, A. Common property institutions and sustainable governance of resources. World Dev. 2001, 29, 1623-1648. 
13. Acheson, J. Capturing the Commons: Devising Institutions to Manage the Maine Lobster Industry; University Press of New England: New Haven, CT, USA, 2003.

14. Carr, M.H.; Neigel, J.E.; Estes, J.A.; Andelman, S.; Warner, R.R.; Largier, J.L. Comparing marine and terrestrial ecosystems: Implications for the design of coastal marine reserves. Ecol. Appl. 2003, 13, 90-107.

15. Board, O.S. Marine Protected Areas: Tools for Sustaining Ocean Ecosystem; National Academies Press: Washington, DC, USA, 2001.

16. Barzel, Y. Economic Analysis of Property Rights; Cambridge University Press: Cambridge, UK, 1989.

17. Van Tatenhove, J. Integrated marine governance: Questions of legitimacy. Marit. Stud. 2011, 10, 87-113.

18. Netting, R.M. Balancing on an Alp; Cambridge University Press: Cambridge, UK, 1981.

19. Clive, G.J.; Lawton, J.H.; Shackak, M. Organisms as ecosystem engineers. OIKOS 1994, 69, 373-386.

20. Ostrom, E.; Gardner, R.; Walker, J. Rules, Games, \& Common-Pool Resources; The University of Michigan Press: Ann Arbor, MI, USA, 1994.

21. Frey, U.J.; Rusch, H. Using artificial neural networks for the analysis of social-ecological systems. Ecol. Soc. 2013, 18, No. 40.

22. Young, O.R. The Institutional Dimensions of Environmental Change: Fit, Interplay, and Scale; Massachusetts Institut of Technology: Cambridge, MA, USA, 2002.

23. Folke, C.; Pritchard, L.; Berkes, F.; Colding, J.; Svedin, U. The problem of fit between ecosystems and institutions: Ten years later. Ecol. Soc. 2007, 12, No. 30.

24. Van Tatenhove, J.P.M. How to turn the tide: Developing legitimate marine governance arrangements at the level of the regional seas. Ocean Coast. Manag. 2013, 71, 296-304.

25. Ostrom, V.; Tiebout, C.M.; Warren, R. The organization of government in metropolitan areas: A theoretical inquiry. Am. Polit. Sci. Rev. 1961, 55, 831-842.

26. Galaz, V.; Crona, B.; Österblom, H.; Olsson, P.; Folke, C. Polycentric systems and interacting planetary boundaries-emerging governance of climate change-ocean acidification-marine biodiversity. Ecol. Econ. 2012, 81, 21-32.

27. Berkes, F. Linkages and multilevel systems for matching governance and ecology: Lessons from roving bandits. Bull. Marine Sci. 2010, 86, 235-250.

28. Glaser, M. Interrelations between mangrove ecosystem, local economy and social sustainability in caeté estuary, north brazil. Wetlands Ecol. Manag. 2003, 11, 265-272.

29. Denzau, A.T.; North, D.C. Shared mental models, ideologies and institutions. Kyklos 1994, 47, 1-31.

30. Schlüter, A. Institutional Change \& Ecological Economics; Mental Models and Sufficient Reason for Understanding Institutional Change. In Institutions and Sustainability: Political Economy of Agriculture and the Environment; Beckmann, V., Padmanaban, M., Eds.; Springer: Berlin, Germay, 2009; pp. 315-339.

31. Song, A.M.; Chuenpagdee, R.; Jentoft, S. Values, images, and principles: What they represent and how they may improve fisheries governance. Mar. Pol. 2013, 40, 167-175. 
32. Agardy, T.; Bridgewater, P.; Crosby, M.P.; Day, J.; Dayton, P.K.; Kenchington, R.; Laffoley, D.; McConney, P.; Murray, P.A.; Parks, J.E.; et al. Dangerous targets? Unresolved issues and ideological clashes around marine protected areas. Aquat. Conserv. Mar. Freshw. Ecosyst. 2003, 13, 353-367.

33. Olson, M. The Logic of Collective Action, Public Goods and the Theory of Groups; Harvard University Press: Cambridge, MA, USA, 1998.

34. Poteete, A.R.; Ostrom, E. Heterogeneity, group size and collective action: The role of institutions in forest management. Dev. Chang. 2004, 35, 435-461.

35. Olson, M. Power and Prosperity; Basic Books: New York, NY, USA, 2000.

36. Knight, J. Institutions and Social Conflict; Cambridge University Press: Cambridge, UK, 1992.

37. Jentoft, S.; Chuenpagdee, R.; Pascual-Fernandez, J.J. What are MPAS for: On goal formation and displacement. Ocean Coast. Manag. 2011, 54, 75-83.

38. Paavola, J.; Adger, W.N. Institutional ecological economics. Ecol. Econ. 2005, 53, 353-368.

39. Scott, R.W. Institutions and Organizations; Sage: London, UK, 2001.

40. Campbell, J.L. Institutional Change and Globalization; University Press: Princeton, NJ, USA, 2004.

41. Schlüter, A. Institutioneller Wandel und Transformation (in German); Shaker: Aachen, Germany, 2001; Volume 3.

42. North, D.C.; Thomas, R.P. The Rise of the Western World: A New Economic History; Cambridge University Press: Cambridge, UK, 1973.

43. Alchian, A.A. Uncertainty, evolution and economic theory. J. Pol. Econ. 1950, LVIII, 211-221.

44. Demsetz, H. Toward a theory of property rights. Am. Econ. Rev. 1967, 57, 347-359.

45. Sened, I. The Political Institution of Private Property; Cambridge University Press: Cambridge, UK, 1997.

46. Bromley, D.W. Searching for Sustainability: The Poverty of Spontaneous Order. In The Economic of Nature and the Nature of Economics; Cleveland, C.J., Stern, D.I., Constanza, R., Eds. Edward Elgar: Cheltenham, UK, 2001; pp. 74-88.

47. Bromley, D.W. Economic Interests and Institutions: The Conceptual Foundations of Public Policy; Basil Blackwell: Oxford, UK, 1989.

48. Hagedorn, K. Particular requirements for institutional analysis in nature-related sectors. Eur. Rev. Agric. Econ. 2008, 35, 357-384.

49. DeLuca, D. One for me and one for you: An analysis of the initial allocation of fishing quotas. New York Univ. Environ. Law J. 2005, 13, 723-768.

50. Jones, P.S. Marine protected area strategies: Issues, divergences and the search for middle ground. Rev. Fish Biol. Fish. 2001, 11, 197-216.

51. Madrigal, R.; Schlüter, A.; Lopez, M.C. What makes them follow the rules?: Empirical evidence from turtle egg harvesters in costa rica. Mar. Pol. 2013, 37, 270-277.

52. UNEP-WCMC. Protected areas and world heritage programme. Available online: http://www.unep-wcmc.org/protected_areas/data/parc.htm (accessed on 30 September 2013).

53. Convention on Biological Diversity. Biodiversity and marine protected areas: Building capacities for the development of regional mpas networks toward effective large marine ecosystem-based management. Available online: http://www.cbd.int/kb/record/sideEvent/2156 (accessed on 30 September 2013). 
54. Pugh, J.; Potter, R.B. Association of American Geographers. In Participatory Planning in the Caribbean: Lessons from Practice; Ashgate: Aldershot, UK, Burlington, VT, USA, 2003.

55. Christie, P. In Marine protected areas as biological successes and social failures in Southeast Asia. Am. Fish. Soc. Symp. 2004, 42, 155-164.

56. McNeely, J.A.; Pitt, D. Culture and Conservation: The Human Dimension in Environmental Planning; Croom Helm Ltd.: Sydney, Australia, 1985.

57. Berkes, F. Evolution of co-management: Role of knowledge generation, bridging organizations and social learning. J. Environ. Manag. 2009, 90, 1692-1702.

58. Plummer, R.; Crona, B.; Armitage, D.R.; Olsson, P.; Tengö, M.; Yudina, O. Adaptive comanagement: A systematic review and analysis. Ecol. Soc. 2012, 17, No. 11.

59. Thomson, K. Development policies, state interventions and struglles for lievelihood rights in coastal communitites in Kerala, India: A case study of the cochin clam fishery. Ocean Coast. Manag. 2009, 52, 586-592.

60. Caveen, A.J.; Gray, T.S.; Stead, S.M.; Polunin, N.V.C. Mpa policy: What lies behind the science? Mar. Pol. 2013, 37, 3-10.

61. Ferse, S.C.A.; Manez Costa, M.; Schwerdtner Manez, K.; Adhuri, D.S.; Glaser, M. Allies, not aliens: Increasing the role of local communities in marine protected area implementation. Environ. Conser. 2010, 37, 23-34.

62. Few, R. Conservation, participation, and power: Protected area planning in the coastal zone of belize. J. Plan. Educ. Res. 2000, 19, 401-408.

63. Tam, C.L. Harmony hurts: Participation and silent conflict at an Indonesian fish pond. Environ. Manag. 2007, 38, 1-15.

64. Adhuri, D. The incident in Westmonsoon: Marine tenure and the politics of village leadership in Maluku, Eastern Indonesia. Marit. Anthropol. Stud. MAST 2004, 3, 5-23.

65. Weber de Morais, G.; Schlüter, A. How can Institutional Analysis Contribute to the Understanding of the Challenges of Marine Protected Areas? Presented at the International Society for Ecological Economics Conference in Lill, Reims, France, 17-18 June 2013.

(C) 2013 by the authors; licensee MDPI, Basel, Switzerland. This article is an open access article distributed under the terms and conditions of the Creative Commons Attribution license (http://creativecommons.org/licenses/by/3.0/). 